\title{
Smallholder Dairy Farming: A Solution to Low Milk Production in Zimbabwe
}

\author{
Washaya $\mathrm{S}^{1 *}$ and Chifamba $\mathrm{E}^{2}$ \\ ${ }^{1}$ University of Fort Hare, Department of Livestock and Pasture Science, Marondera University of Agricultural Sciences and Technology, Department of \\ Animal Science, Zimbabwe
}

${ }^{2}$ Dairyboard Zimbabwe Limited, H.O.D. Milk Supply Development, Zimbabwe

Submission: November 12, 2018; Published: November 21, 2018

*Corresponding author: Washaya S, University of Fort Hare, Department of Livestock and Pasture Science, Marondera University of Agricultural Sciences and Technology, Department of Animal Science, Zimbabwe

\begin{abstract}
Thirty-five years after the smallholder dairy farming program was initiated, milk intake is still below average in Zimbabwe. Several reasons have been identified to limit optimum milk production and these include; inappropriate breeds, inadequate feed supply, lack of government support, cost of production, poor marketing channels, poor disease control methods, inadequate infrastructure, weak extension support, lack of farmer involvement in production planning, poor social relations between farmers and management. Regrettably none of the limitations have been adequately addressed within the context of a smallholder dairy farmer; therefore, the initiative has not been fully tested for or against. The reliance on well-wisher funds by local authorities in this farming sector cannot be a solution to improving milk production. There is need for control mechanism and proper budgeting of available funds towards capacitating of smallholder dairy farmers.
\end{abstract}

Keywords: Smallholder; Dairy production; Milk deficit

Abbreviations: DDP: Dairy Development Program; ARDA: Agricultural and Rural Development Authority; NOARD: Norwegian Agency for Development; DANIDA: Danish International Development Agency; PSIP: Public Sector Investment Program; HP: Heifer Project International

\section{Introduction}

The demand for milk and milk products in Zimbabwe has been growing over time in synergy with population growth. This trend has outweighed production potential which is currently at 54.3 million liters against a demand of 120 million liters per annum [1] for over three decades and until now per capita milk consumption remains below world average. The country used to produce 262 million liters per annum [2]. In a bid to increase milk output the Zimbabwean government introduced the small-scale dairy farming schemes in 1983 under the Dairy Development Program (DDP). The Agricultural and Rural Development Authority (ARDA) was mandated to spearhead commercialization of this project. At inception, the program was funded by the Norwegian Agency for Development (NORAD), Africa Now (UK), the Danish International Development Agency (DANIDA), Heifer Project International (HP) and the Government of Zimbabwe through the Public Sector Investment Program (PSIP) [3-5]. This developmental program mainly concentrated in the medium to high rainfall areas of Zimbabwe $[6,7]$.

In 1998, the program was then extended to semiarid areas, which were initially described as unsuitable for dairy farming [8]. In addition, the development efforts in these semiarid areas targeted resettled farms that had potential to grow fodder as it was the major factor limiting smallholder dairy farming $[9,10]$. Thirty-five years after these initiatives per capita milk consumption has dwindled, and national milk production has gone down by more than $50 \%$ making the country a net importer of milk and dairy products. There is therefore needing to revisit the initiatives with the aim of improving milk production throughout the country.

\section{Discussion}

Dairying in the smallholder sector is practiced for reasons other than profit making, which are feeding the family, to produce manure to support crop production and to provide dairy animals as insurance, for financing emergency cash needs and for social status [11] then, surplus milk can be sold to nearby markets. From a smallholder dairy farmers' perspective, dairying assists farmers to diversify, spread farming risks and creates opportunity to make use of idle resources like crop residues [5]. This was not the governments' intention for this initiative. There could be several reasons for this farmers' approach including but not limited to failure to conceptualize the business model, lack of adequate support from private and public partners [12], inappropriate breeds [13] cost of production [14], and poor milk yields [15]. 
Although dairy production in Zimbabwe has been dominated by large scale commercial farmers and company owned dairy farms, the trends in milk production in this sector has also been declining (Table 1), this possess an ample opportunity for smallholder dairy sector to contribute positively and immensely to local milk production. However, the situation is more complex than that, because the smallholder sectors' contribution has also been on the decline. Data available from the DDP indicate that

Table 1: Trends in the Large scale dairy subsector of Zimababwe. milk production within the smallholder sector fluctuated from 2.7 million liters in 1990 to 1.5 million liters in 1998 and 1.13 million liters in 2011. Several reasons have been identified as causes for this low productivity. These include inappropriate breeds, insufficient knowledge on the farming objectives, and poor extension advice which has led farmers to shift from one breed to another [16]. Furthermore; shortage of fodder; limited fodder production and poor disease control measures [17].

\begin{tabular}{|c|c|c|c|c|c|c|c|c|c|}
\hline Year Variable & 2000 & 2001 & 2002 & 2003 & 2004 & 2005 & 2006 & 2010 & 2012 \\
\hline Registered producers & 314 & 323 & 283 & 280 & 277 & 281 & 282 & 165 & 165 \\
\hline Cows in milk & 29975 & 28321 & 28845 & 27667 & 23788 & 22687 & 23200 & 18000 & 20000 \\
\hline Total females' dairy animals & 70142 & 66270 & 67496 & 64742 & 55300 & 47521 & 47520 & 37750 & 42500 \\
\hline Milk intake (million litres) & 177 & 172 & 149 & 111 & 94 & 102 & 96 & 47.2 & 64.4 \\
\hline Average production per cow per yr (litres) & 4542 & 4671 & 4047 & 3095 & 3076 & 3391 & 3206 & 2052 & 2500 \\
\hline
\end{tabular}

Evidence presented by many authors points to the fact that dairy farming is a high capital-intensive adventure, that requires proper planning and a consistent supply of capital goods and services. This has been the greatest challenge for smallholder dairy farming in Zimbabwe. Furthermore, there is lack of government control and direct involvement in directing available funding by NGOs to address limitations already identified, rather each project will have its own objectives and there is lack of collaboration and corroboration within and without government.

\section{Conclusion}

There is great potential in smallholder dairy farming, which if tapped, can significantly reduce milk and milk product deficits in Zimbabwe. A holistic approach to famer circumstances coupled with adequate training is necessary to increase productivity. Development of appropriate breeds, adequate feeding and control of diseases are key to smallholder dairy farming.

\section{References}

1. Livestock \& Meat Advisory Council (LIMAC) (2018) Livestock market update.

2. SNV (2016) Zimbabwe's dairy subsector study.

3. Mapiye C, Foti R, Mwale M, Chikumba N, Poshiwa X, et al. (2006) Constraints to adoption of forage and browse legumes by Smallholder Dairy Farmers in Zimbabwe. Livestock Research for Rural Development 18: 12.

4. Ngongoni NT, Mapiye C, Mwale M, Mupeta B (2006) Factors affecting milk production in the smallholder dairy sector in Zimbabwe. Livestock Research for Rural Development 18: 5.

5. Ngongoni NT, Mapiye C, Mwale M, Mupeta B (2007) Effect of supplementing a high-protein ram press sunflower cake concentrate on smallholder milk production in Zimbabwe. Tropical Animal Health and Production 39(4): 297-307.

6. Garwe EC (2007) The current state of dairy research and strategic dairy research to enhance dairy production in Zimbabwe. In: Reviving the Zimbabwean Dairy Industry; Proceedings of the National Dairy Symposium held from 5 to 6 July 2007 in Harare, Zimbabwe p. 1-20.
7. Muchenje V, Chimedza-Graham R, Sikhosana JLN, Assan N, Dzama $\mathrm{K}$, et al. (2007) Milk yield of Jersey x Nguni and Tuli F1 and F2 cows reared under small holder farming conditions. South African Journal of Animal Science 8: 7-10.

8. Garwe E, Ball PJH, Hamudikuwanda H, Mutisi C (2001) Reproductive performance of indigenous and cross-bred cows developed for milk production in semi-arid regions and the effect of feed supplementation. In: Sustaining livestock in challenging dry season environments: strategies for small scale livestock keepers; Proceedings of the third workshop on livestock production programmes, Ingwe Lodge and ICRISAT, Matobo, Natural Resources International Ltd, Kent, UK p. 6371.

9. Jingura RM, Sibanda S, Hamudikuwanda H (2001) Yield and nutritive value of tropical forage legumes grown in semi-arid parts of Zimbabwe. Tropical Grasslands 35: 168-174.

10. Mapiye C, Mwale M, Mupangwa JF, Mugabe PH, Poshiwa X, et al. (2007) Utilization of ley legumes as livestock feed in Zimbabwe. Tropical Grasslands 41: 84-91.

11. Bebe OB, Udo HMJ, Rowlands GJ, Thorpe W (2003) Smallholder dairy systems in the Kenya highlands: breed preferences and breeding practices. Livestock Production Science 82: 117-127.

12. SNV (2012) Evaluation of Smallholder Dairy Programmes in Zimbabwe.

13. Marius LN, Imbayarwo-Chikosi EV, Hanyani-Mlambo BT, Mutisi C (2011) Breed preferences, production performance and management of dairy cattle among selected smallholder dairy farmers of Zimbabwe.

14. Hahlani CD, Garwi J (2014) Operational challenges to smallholder dairy farming: The case of Mayfield Dairy Settlement Scheme in Chipinge District of Zimbabwe. IOSR Journal of humanities and Social Science 19(1): 87-94.

15. Chinogaramombe GNC, Muchenje V, Mapiye C, Ndlovu T, Chimonyo M, et al. (2008) Challenges for improving smallholder dairy production in the semiarid areas of Zimbabwe. Livestock Research for Rural Development 20: 3 .

16. Smith T, Moyo S, Richards JI, Morton JF (2002) The role of indigenous and cross-bred cattle for smallholder dairy production in Zimbabwe. Harare, Zimbabwe.

17. Munangi $W$ (2007) Strategies for improving the contribution of Smallholder Dairy Sector to Supply milk in Zimbabwe. In Proceedings, National Dairy Symposium on Reviving the Zimbabwe Dairy Industry. Harare, Zimbabwe. 
Your next submission with Juniper Publishers will reach you the below assets

- Quality Editorial service

- Swift Peer Review

- Reprints availability

- E-prints Service

- Manuscript Podcast for convenient understanding

- Global attainment for your research

- Manuscript accessibility in different formats

( Pdf, E-pub, Full Text, Audio)

- Unceasing customer service

Track the below URL for one-step submission https://juniperpublishers.com/online-submission.php 